\title{
Synthesis and Biological Activity of New Antifungal Compounds: A Preliminary Study
}

\author{
Jorge A. Cabezas ${ }^{\#}$, José A. Brenes ${ }^{\#}$, Norma Gross^ and María L. Arias^ \\ "School of Chemistry, University of Costa Rica, San José, 2060, Costa Rica \\ Tropical Disease Research Center (CIET) and Faculty of Microbiology, University of Costa Rica, San José, 2060, Costa Rica
}

Received 05 July 2018, Accepted 08 Sept 2018, Available online 11 Sept 2018, Vol.6 (Sept/Oct 2018 issue)

\begin{abstract}
In the present study, we synthesized three 1,3-enynes from their corresponding aldehydes. They exhibited antifungal activity, which was evaluated against Trichophyton rubrum, the most common dermatophyte responsible for nail infection. The biological activity of these synthetic enynes was compared to terbinafine and ciclopirox olamine, two common antimycotic drugs used to treat nail infections caused by this pathogen. Two of these compounds showed an inhibitory effect similar to terbinafine and cilopirox olamine, when tested against over eleven different T. rubrum strains, including ATCC 28188 strain and ten different clinical isolates, two already classified as multitreated.
\end{abstract}

Keywords: 1,3-enynes, 1,3-dilithiopropyne, propargylation, antifungal, onychomycosis, Trichophyton rubrum

\section{Introduction}

Onychomycosis is defined as a fungal infection of the nail. It affects toenails and fingernails, however it is known that toenails are 4 to 10 times more prone to infections than fingernails [1]. It occurs in about $10 \%$ of the adult population [2] and up to $90 \%$ of the older adults may be affected. Typically, these infections are characterized by white-yellow-brown discoloration of the nail, thicker and chalkiness nail plate and hyperkeratosis of nail bed.

The pathogens causing these infections include three types of fungi: dermatophytes, yeast and nondermatophytic molds. More than $90 \%$ of toenail infections and more than $50 \%$ of fingernail infections are caused by dermatophytes [1],[3].

Dermatophytes represent a specialized group of fungi, commonly associated with cutaneous disease both for humans and animals [4]. They are keratinophilic microorganisms, capable of infecting superficial keratinized tissues, including skin, hair and nails [5].

The most common dermatophytes responsible for nail infection are Trichophyton rubrum and Trichopyton mentagrophytes [3]. Nevertheless some yeast like Candida albicans, Candida parapsilosis and some nondermathophytes moulds, such as Fusarium, Neoscytalidium, Scopulariopsis and Aspergillus are primary pathogens in some cases of fingernail onychomycosis [6]. In recent years, the number of

*Corresponding author's ORCID ID: 0000-0002-7571-6914 DOI: https://doi.org/10.14741/ijmcr/v.6.5.5 infections caused by this group of fungi has increased significantly, representing a risk especially for immunecompromised patients, where severe and atypical manifestations may occur [7]. Also, the emergence of drug resistant forms has become a topic of concern [8].

Many antimycotic drugs have been developed during the past 40 years to treat fungal infections. Due to the slow-grow of nails, treatment of onychomycosis generally involves long-term therapy. Normally it consists of topical ointments applied directly to the nail, in cases of mild infections. This topical therapy has limited success due to poor permeability of applied drugs through the nail [9]. In cases of more severe infections, classic systemic drugs such as griseofulvin, $\mathbf{1}$, and ketoconazole, 2, have been used for a long time. These drugs must be used for long periods of time (10-18 months) and the major side effects of these drugs are liver toxicity and gastrointestinal and systemic side effects. Their relapse rate is $50-85 \%$.

Griseofulvin, 1, was first isolated in 1939 [10] from filamentous fungi Penicillium griseo-fulvum, and has been used as antifungal drug for decades. Some of its side effects include nausea, diarrhea and also has some teratogenic effects when used before pregnancy. Nowadays, this antifungal is not recommended to treat nail infections.

Ketoconazole, 2, an imidazole class compound, discovered in 1976 at Janssen Pharmaceuticals, was introduced in U.S.A. in 1977 (Nizoral®). However, because it can cause serious liver injury, in 2013 the European Medicines Agency recommended to ban it for systemic use in the European Union [11]. In U.S.A. has 
been replaced by the triazoles, itraconazole, $\mathbf{3}$ and fluconazole, 4. Oral antifungal treatments with itraconazole, $\mathbf{3}$ and fluconazole, $\mathbf{4}$ are taken for at least 12 months and have better cure rates and fewer side effects than Ketoconazole, 2. However, they are associated with a marked increased risk of clinical acute liver injury [12]. Azole drugs inhibit the enzyme 14- $\alpha$-lanosterol demethylase in ergosterol biosynthesis (the main fungal sterol), resulting in depletion of ergosterol and accumulation of toxic 14- $\alpha$-methylated sterols in membranes of susceptible fungal species, having a fungistatic action.

The synthetic antifungal agent ciclopirox olamine, 5, unrelated with imidazole derivatives, was approved by the FDA in 2006, and has been used in lacquers for treatment of superficial onychomycosis due to Trichophyton rubrum and Trichophyton mentagrophytes. In open and placebo-controlled studies, in patients with superficial dermatophyte or yeast infections, topical ciclopirox olamine, $\mathbf{5}$, was comparable to or better than clotrimazole, $\mathbf{6}$, in efficacy [13].

Terbinafine, 7, was discovered in 1984 [14], and it was found to have higher activity than drugs such as ketoconazole, 2, griseofulvin, $\mathbf{1}$, econazole, $\mathbf{8}$, and tolnaftate, $\mathbf{9}$, in oral and topical treatment of guinea pig dermatophytoses [15]. Terbinafine, 7 has been used orally, to treat superficial toenail and fingernail infections, since 1996. It has the advantage that it concentrates in keratin-rich tissues, and it has a fungicidal effect [16]. It has been reported that it is less toxic to the liver than griseofulvin, 1, and ketoconazole, 2 [17]. However when given orally, adverse effects such as hepatocellular necrosis and cholestatic injury has been reported [18]. The period of time between the start of medication and the development of the liver injury is about 4-6 weeks [12].

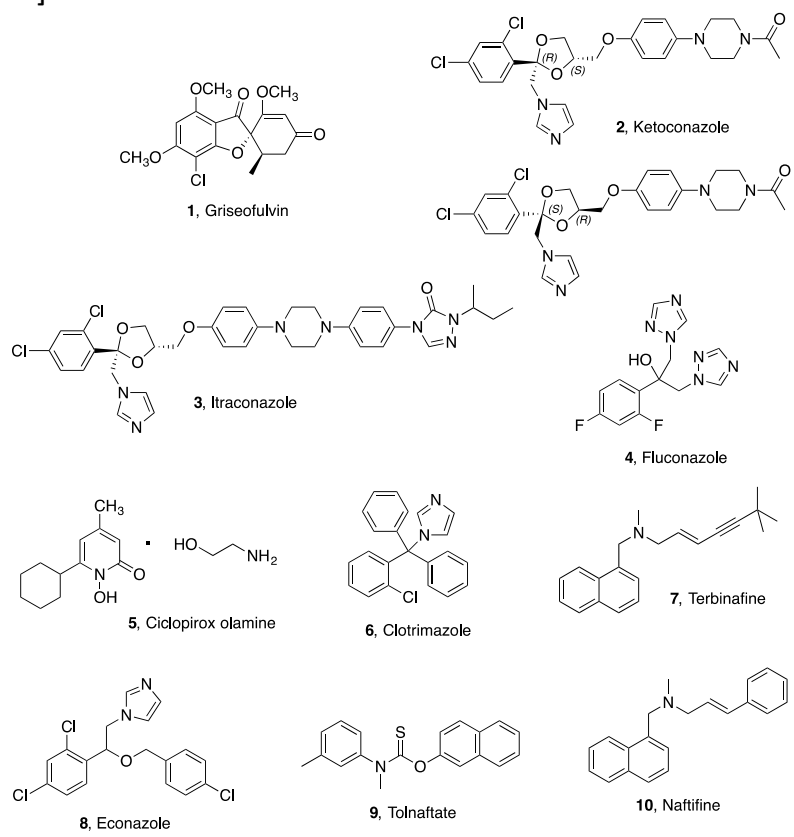

Figure 1 Example of some compounds with antifungal activities
It is thought that terbinafine, 7, like other allylamines such as naftifine, $\mathbf{1 0}$, binds to fungal squalene epoxidase, inhibiting ergosterol synthesis from squalene. This results in a deficiency of ergosterol changing its permeability and causing fungal cell lysis. Also this provokes an increase of the intracellular concentration of squalene, ultimately disrupting and damaging the cell wall, resulting in a fungicidal action [19].

The first antifungal compound of the allylamine-type was naftifine, 10, [(E)-N-methyl- $N$-(1-naphtylmethyl)-3phenylallylamine]. Some structure-activity studies, based on naftifine, $\mathbf{1 0}$, lead to the discovery of the more active compound terbinafine, $\mathbf{7}$, first pharmaceutical agent to contain a (E)-1,3-enyne in its chemical structure [20]

The development of different and novel antifungal drugs has been a primary objective for the scientific community. These innovative drugs must have different modes of action compared with actual antifungals, so that no cross-resistance appears. Nevertheless few marketed antifungal drugs have been introduced lately [21]. In the present study, a terbinafine-derivative 11, and two new highly active 1,3-enynes 12 and 13, were thus evaluated. These compounds were prepared by a synthetic methodology we developed, that allowed us to convert aldehydes and ketones into 1,3-enynes in a one-pot reaction [22]. The antifungal activity of these synthetic derivatives against Trichophyton rubrum was measured, and compared to terbinafine $\mathbf{7}$ and ciclopirox olamine $\mathbf{5}$.

\section{Results and Discussion}

\subsection{Synthesis}

Antifungal agents such as naftine, 10, and terbinafine, $\mathbf{7}$, are classified as allyl amine-type. It has been found that the tertiary $(E)$ allyl amine unit is essential for its biological activity [23]. Furthermore, two lipophilic groups (tert-butyl and naphthalene) linked by a polar spacer of a proper length, are needed for the biological activity of terbinafine, 7 [24].

We decided to use a recently developed procedure [22], for the one-pot conversion of aldehydes and ketones into 1,3-enynes, to prepare three compounds containing this enyne framework $(\mathbf{1 1}, \mathbf{1 2}$, and $\mathbf{1 3})$, and to measure its activity against Trichophyton rubrum.

Enyne 11, was prepared from aldehyde 18. The synthesis of 18, initiated with reaction of 1 naphthylmethylamine, 14 , with $n$-BuLi at $0^{\circ} \mathrm{C}$, followed by treatment with bromoacetaldehyde diethyl acetal, 15, to obtain the corresponding amino ketal 16, in $94 \%$ yield (Scheme 1). The amine 16 was treated with $n$-BuLi at $0^{\circ} \mathrm{C}$, followed by reaction with methyl iodide to obtain, after stirring overnight, the methylated derivative, 17, in quantitative yield (Scheme 1). To de-protect the keta group many methods [25] were unsuccessfully used. Refluxing compound 17, in glacial HOAc generated aldehyde 18, which rapidly decomposed in the acidic media as it was formed, as corroborated by GC-MS 
analyses of aliquots taken from the reaction mixture. Refluxing ketal 17, for 8 hours, with acetone in the presence of $\mathrm{FeCl}_{3}$ also failed to produce aldehyde 18. In this case, it was thought that the amine, present in 17, could be coordinating strongly with Lewis acid $\mathrm{FeCl}_{3}$, deactivating its catalytic function. Thus, we repeated this reaction but adding a few drops of $\mathrm{HCl} 6 \mathrm{~mol} / \mathrm{L}$, to form the corresponding ammonium chloride salt of amine 17. In this case, the desired aldehyde 18 , was obtained in $80 \%$ yield (calculated by GC).<smiles>NCc1cccc2ccccc12</smiles>

14<smiles>CCOC(CNCc1cccc2ccccc12)OCC</smiles>
16

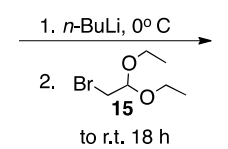
to r.t. $18 \mathrm{~h}$
1. $n$-BuLi, $0^{\circ} \mathrm{C}$,<smiles>CCOC(CN(C)Cc1cccc2ccccc12)OCC</smiles>
reflux, $8 \mathrm{~h}$

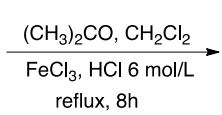

Scheme 1 Sythensis of aidehyde 18

Several attempts to isolate aldehyde $\mathbf{1 8}$, by column chromatography, resulted in decomposition of the product. This synthesis was repeated, and the crude reaction, containing this aldehyde, $\mathbf{1 8}$, was taken into the next reaction step, without any further purification. Thus, we reacted aldehyde, 18, with dianion "1,3dilithiopropyne", 19, which was prepared by treatment of 2,3-dichloropropene, 20, with magnesium, followed by reaction with $n$-BuLi (Scheme 2) [22], [26]. The intermediate, $\mathbf{2 1}$, formed by addition of $\mathbf{1 9}$, to $\mathbf{1 8}$, was reacted with tosyl chloride, followed by elimination with tert-BuLi to afford, after aqueous work-up and column chromatography, enyne, 11, in $90 \%$ yield (Scheme $\mathbf{2}$ ).

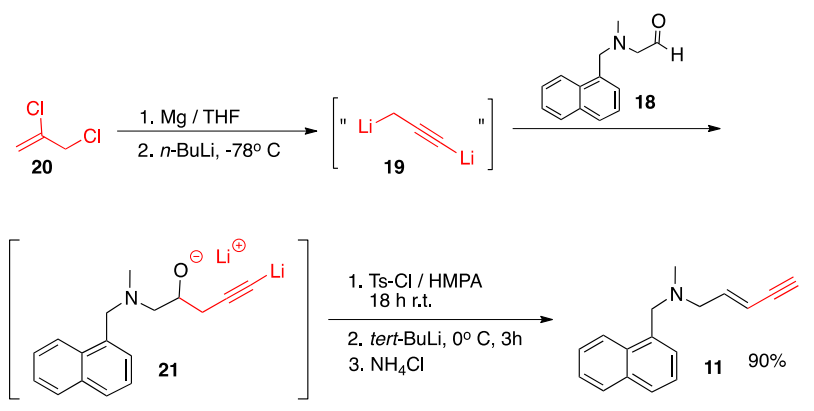

Scheme 2 Synthesis of enyne 11

1,3-Enyne, 12, was prepared by reaction of 1,3dilithiopropyne, 19, with $p$-dimethylaminobenzaldehyde, 22, as previously described. This reaction gave product 12, as a trans:cis isomeric mixture in a ratio of 9:1, in $53 \%$ yield (Scheme 3).

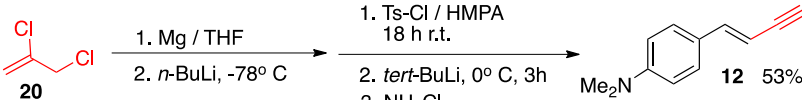

$$
\begin{aligned}
& 3 .
\end{aligned}
$$

Scheme 3 Synthesis of enyne 12

We decided to add a formyl group to the triple bond of enyne, 12, to extend conjugation and possibly reactivity. Thus, we repeated reaction between $p$ dimethylaminobenzaldehyde, 22, with dianion, 19, and the reaction was quenched by addition of 4formylmorpholine, 23, to obtain, after aqueous work-up and column chromathography, aldehyde 13 in $18 \%$ overall yield (Scheme 4). Because this formylation process gave very poor yields, we decided to prepared aldehyde 13 by an alternative route.

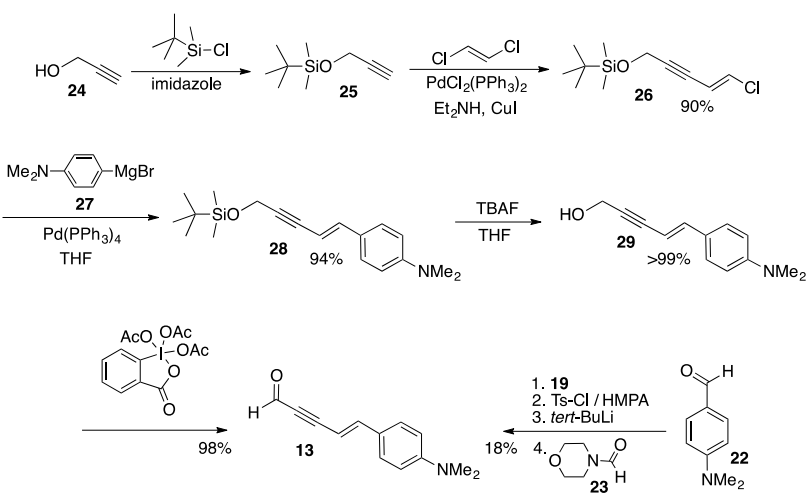

Scheme 4 Synthesis of enyne 13

Protection [27] of propargyl alcohol, 24, gave the corresponding silyl ether, $\mathbf{2 5}$, wich was treated with transdichloroethylene, under Sonogashira reaction conditions, to obtain chloro enyne, $\mathbf{2 6}$, in $90 \%$ yield. Palladium crosscoupling chemistry of this vinyl chloride, 26, with 4dimethylamino phenylmagnesium bromide, 27, afforded enyne, 28, in $94 \%$, which upon treatment with tetrabutylamonnium fluoride gave alcohol, 29 in quantitative yield. Dess-Martin oxidation of alcohol, 29, afforded desired aldehyde 13 in $98 \%$ and $82 \%$ overall yield (Scheme 4).

\subsection{Antifungal Activity}

The inhibitory effect of compounds 12, 13 and terbinafine, 7, was tested over a $1,0 \times 10^{4}$ spores $/ \mathrm{mL}$ concentration of $T$. rubrum. Compound $\mathbf{1 2}$ showed a very weak activity, which disappeared at a concentration of $1,25 \mathrm{mg} / \mathrm{mL}$, while compound 13 showed a behavior similar to terbinafine, 7. This is shown on Figure 2, where the minimal inhibitory concentration obtained for compound 13 and terbinafine, 7, was of $4 \mathrm{~g} / \mathrm{ml}$. 


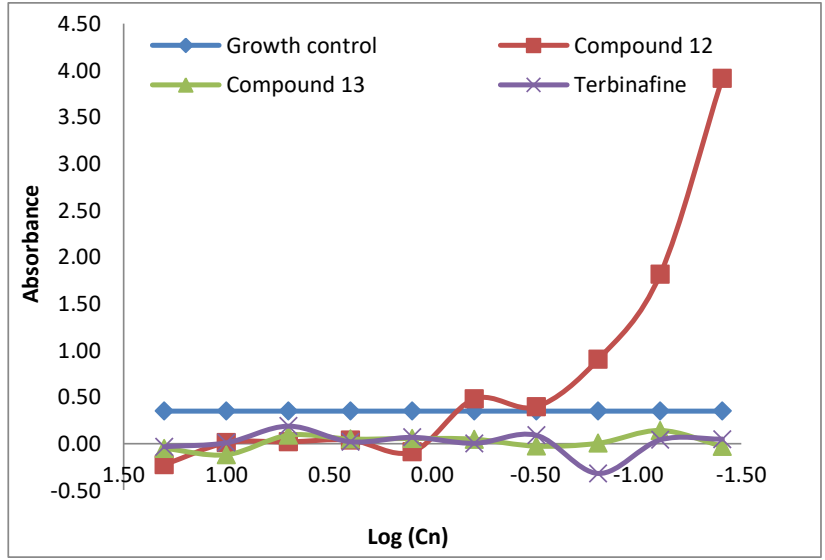

Figure 2. Inhibitory effect of compounds 12,13 and terbinafine, 7 , over a $1.0 \times 10^{4}$ spores $/ \mathrm{mL}$ concentration of $T$. rubrum.

The inhibitory effect of compound $\mathbf{1 3}$ and terbinafine, 7, over a $1,0 \times 10^{7}$ spores concentration of $T$. rubrum, was then tested. Both compounds showed a notorious, and similar, inhibitory effect over this dermatophyte (Figure 3).

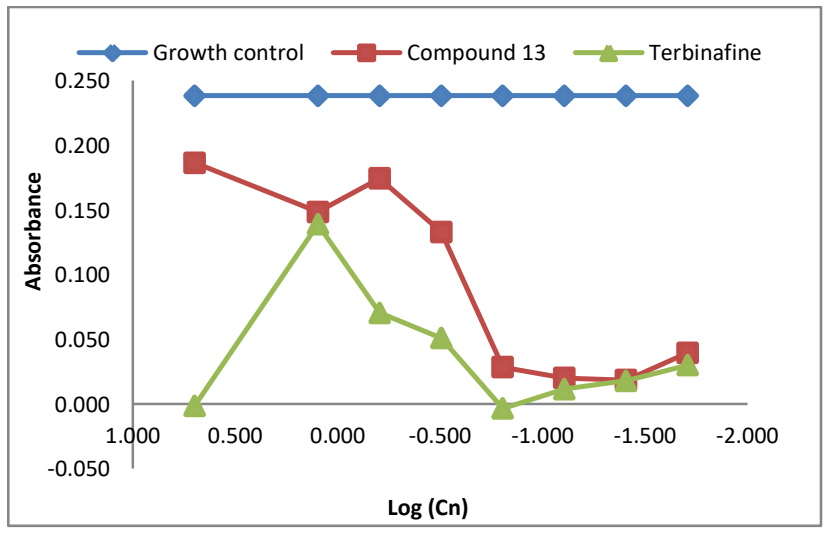

Figure 3. Inhibitory effect of compound $\mathbf{1 3}$ and terbinafine, 7 , over a $1.0 \times 10^{7}$ spores $/ \mathrm{mL}$ concentration of spores of $T$. rubrum

The inhibitory effect of compounds $\mathbf{1 2}, \mathbf{1 3}$, terbinafine, $\mathbf{7}$ and ciclopirox olamine, $\mathbf{5}$, over eleven different $T$. rubrum strains, was determined. This study included ATCC 28188 strain and ten different clinical isolates, two already classified as multitreated ( 9 and 10 ), the comparison of these results is shown on Table 1.

Table 1. Comparison of inhibitory effect of compounds 12, 13, terbinafine, $\mathbf{7}$, and ciclopirox, 5, over T. rubrum

\begin{tabular}{|c|c|c|c|c|c|}
\hline$\frac{\text { 응 }}{\sum}$ & 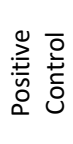 & 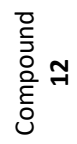 & $\begin{array}{l}\frac{x}{0} \\
\frac{0}{\circ} \\
\frac{0}{0} \\
\frac{0}{U}\end{array}$ & 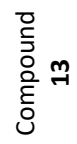 & 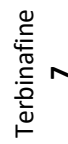 \\
\hline 1 & + & + & + & + & + \\
\hline
\end{tabular}

\begin{tabular}{|c|c|c|c|c|c|}
\hline 2 & + & + & - & - & + \\
\hline 3 & + & + & - & - & - \\
\hline 4 & + & + & - & - & - \\
\hline 5 & + & + & - & - & - \\
\hline 6 & + & + & - & - & - \\
\hline 7 & + & + & - & - & - \\
\hline 8 & + & + & - & - & - \\
\hline $9^{\text {a }}$ & + & + & - & + & - \\
\hline $10^{\text {a }}$ & + & + & + & + & + \\
\hline 11 & + & + & - & - & - \\
$($ ATCC) & + & + & - & & \\
\hline
\end{tabular}

${ }^{\mathrm{a}}$ Multitreated. ${ }^{\mathrm{b}}(+)$ growth, $(-)$ inhibition. ${ }^{\mathrm{c}}$ All trials were performed 4 times

Compound $\mathbf{1 2}$ does not inhibit any of the strains tested, but compound 13 inhibits 73\% of the strains, a behavior similar to terbinafine, $\mathbf{7}$. Only ciclopirox, 5, inhibited $88 \%$ of strains. There is no statistical difference between terbinafine, 7, ciclopirox, $\mathbf{5}$, and compound $\mathbf{1 3}$ on the growth inhibition of $T$. rubrum ( $p>0,05)$.

In addition, the inhibitory effect of synthetic derivative, 11, was tested over a $1,0 \times 10^{4}$ spores $/ \mathrm{mL}$ concentration of $T$. rubrum, and these results were compared to terbinafine, 7, (Figure 4). This result indicates that compound $\mathbf{1 1}$ exhibit an excellent in vitro inhibitory effect against $T$. rubrum; this inhibition is as good as the one shown by terbinafine, 7 .

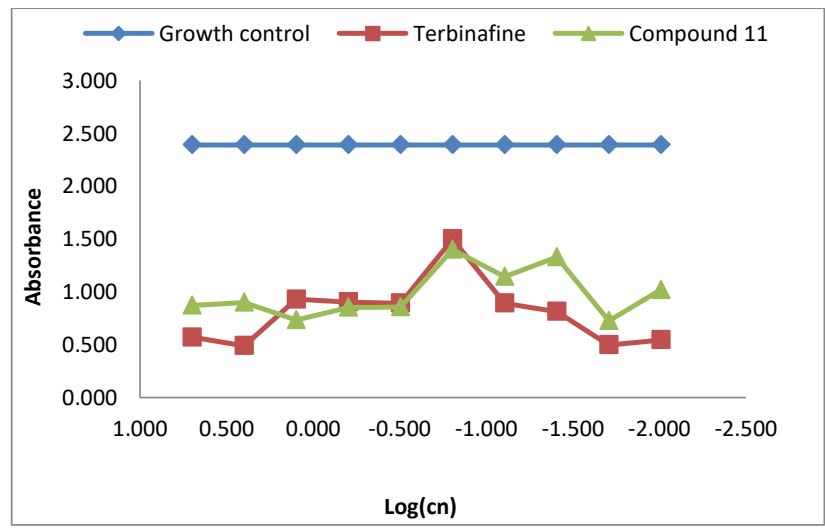

Figure 4. Inhibitory effect of compound 11 and terbinafine over a $1.0 \times 10^{4}$ spores $/ \mathrm{mL}$ concentration of $T$. rubrum

Several categories of antifungal agents have been introduced into the market and routinely used, including itraconazole, 3, fluconazole, 4, and terbinafine, 7 Nevertheless, there are several communications of bad therapeutic outcomes worldwide [28], of interactions with administrated drugs, which results in adverse clinical consequences [29] as well of an increasing development of resistance against them [30]. This situation has led to the development of several studies of the in vitro susceptibility of dermatophytes to new antifungal drugs, and the results have shown important variations, which may be due to methodological differences.

Although there are several antifungal agents very active against dermatophytes, it is important to point out 
that results obtained are species dependent and the development of resistance is probable, especially with dermatophytosis associated to T. rubrum [8].

\section{Conclusions}

In this study we developed one-pot syntheses, for compounds 11, 12 and 13 (Schemes 1-4). Compound 13, was also synthesized by an alternative and longer route, but with better yields (Scheme 4).

Compounds 12,13 , were evaluated over a $1.0 \times 10^{4}$ and $1.0 \times 10^{7}$ spores $/ \mathrm{mL}$ concentration of T. rubrum and its biological activity compared to terbinafine, 7. From these trials it was found that compound $\mathbf{1 3}$, showed a similar inhibitory effect than terbinafine, $\mathbf{7}$.

Compound 13, also showed a similar inhibitory effect than terbinafine, 7, and cilopirox olamine, 7, when tested against over eleven different $T$. rubrum strains, including ATCC 28188 strain and ten different clinical isolates, two already classified as multitreated. In these cases there were no statistical differences between terbinafine, $\mathbf{7}$, ciclopirox, 5, and compound $\mathbf{1 3}$ over the growth inhibition of $T$. rubrum $(\mathrm{p}>0,05)$.

Additionally, the comparison of inhibitory effects of synthetic derivative, $\mathbf{1 1}$, and terbinafine, $\mathbf{7}$, over a $1,0 \times$ $10^{4}$ spores $/ \mathrm{mL}$ concentration of $T$. rubrum, indicated that compound $\mathbf{1 1}$ has, in vitro, an inhibitory effect as good as the one shown by terbinafine, 7 .

\section{Experimental section}

\subsection{Microbial trials}

\subsubsection{Test isolates}

A total of 11 Trichophyton rubrum strains, including 10 clinical dermatophyte isolates and ATCC28188 were tested. All microorganisms are part of the Dermatophyte collection of the Medical Mycology Laboratory, University of Costa Rica.

\subsubsection{Preparation of the fungal inoculum}

T. rubrum was grown for 7 days at $35^{\circ} \mathrm{C}$ in test tubes containing Oatmeal agar. Spores were harvested by flooding test tubes with $85 \%$ sterile saline $(1 \mathrm{ml})$, and lightly scraping the agar surface with a cotton swab. The spores were then counted in a Bürker hemocytometer and diluted in RPMI 1640 Medium ${ }^{\circ}\left(\mathrm{Gibco}^{\mathrm{TM}}\right.$, Waltham, MA,USA) to a concentration of $1,5 \times 10^{4}$ and $1,5 \times 10^{7}$ spores/ml for tests of minimal inhibitory concentration determinations and to a concentration of $1,5 \times 10^{7}$ spores/ml for growth inhibition tests.

\subsubsection{Antifungal tested and dilutions}

Compounds A and D, as well as terbinafine (Royal Pharma) and clorpirox (Jinlan Prham Drugs) standards were prepared at a $10 \mathrm{mg} / \mathrm{mL}$ concentration. Ten double dilutions were prepared using DMSO (dimethyl sulfoxide) for each product

\subsubsection{Comparison of the Minimal Inhibitory Concentration (MIC) of products $A$ and $D$ against terbinafine}

Microtiter plates were inoculated with $100 \mu \mathrm{L}$ of RPMI 1640 media, $100 \mu \mathrm{L}$ of the T. rubrum spores and $100 \mu \mathrm{l}$ of either products A, D or terbinafine dilutions. Growth and sterility controls were included for each test (growth controls consisted of spores, DMSO and RPMI 1640 media, sterility controls of RPM1 medium and DMSO only). Each trial was done by duplicate. Inoculated plates were incubated at $28^{\circ} \mathrm{C}$ for 4 days.

MIC was determined using Biotek Synergy HT multidetection reader (Vermont, US). Protocol followed included $450 \mathrm{~nm}$ lectures in order to determine the absorbance. The optic density of growth control wells were assumed as $100 \%$ growth. According to the microdilution reference method CLSI M38-A2 (Clinical Laboratory Standards Institute. Reference method for broth dilution antifungal susceptibility testing of filamentous fungi. Approved standard M38-A2. 2nd edition Wayne, PA: Clinical and Laboratory Standards Institute, 2008), final point was determined as $80 \%$ inhibition of this value, thus MIC was determined as the concentration of the last well where the optic density was $20 \%$ less of growth control.

4.1.5. Comparison of the efficacy on products $A, D$, terbinafine and ciclopirox in the growth inhibition of different $T$. rubrum samples.

For this test, 11 different isolates of $T$ rubrum, including ATCC 28188 and prepared as described above were evaluated.

Sabouraud dextrose agar plates with a final concentration of $20 \mu \mathrm{g} / \mathrm{mL}$ of either compound $A, D$, terbinafine or ciclopirox were inoculated in four different spots with $50 \mu$ l of a $1,0 \times 10^{7} \mathrm{~T}$. rubrum spores $/ \mathrm{mL}$ of each sample. Agar plates were incubated at $28^{\circ} \mathrm{C}$ and in humid chamber for 10 days, in order to see the mold classical growth. Each sample was analyzed three different times.

\subsection{Chemistry}

General: All glassware and syringes were dried in an oven overnight at 140 $\mathrm{C}$ and flushed with nitrogen immediately prior to use. Transfers of reagents were performed with syringes equipped with stainless-steel needles. All reactions were carried out under a positive pressure of nitrogen. Nitrogen was passed through a Drierite gas-drying unit prior to use. Diethyl ether and tetrahydrofuran were refluxed and freshly distilled from sodium and potassium/benzophenone ketyl respectively, under nitrogen atmosphere. Hexane was distilled from 
sodium and collected and kept over activated molecular sieves. $n$-Butyllithium was titrated according to the method of Watson and Eastham [31]. ${ }^{1} \mathrm{H}-\mathrm{NMR}$ and ${ }^{13} \mathrm{C}$ NMR spectra were recorded on a $400 \mathrm{MHz}$ Bruker spectrometer. Low-resolution mass spectra were obtained on Agilent Technologies 7820A GC coupled to a mass spectrometer $5977 \mathrm{E}$ unit using electron impact at $70 \mathrm{eV}$. High resolution mass were measured on a Waters Synapt HMDS G1, Q-TOF. Infrared spectra were recorded on a Perkin Elmer FT-IR Spectrum 1000.

\subsection{General procedure for the preparation of 1, 3- dilithiopropyne 19:}

An oven-dried, $100 \mathrm{~mL}$, three-necked, round-bottomed flask was equipped with a magnetic stirring bar and a Liebig condenser bearing a glycerin-bubbler at the top. The exit of the bubbler, bearing a septum, was punctured with a double-tipped needle, whose other end was inserted, through a rubber septum, into a two-necked flask equipped with a magnetic stirring bar. The other neck of this flask was capped by a rubber septum bearing a needle attached to a balloon. All joints were greased and secured with parafilm. The three-necked flask was charged with magnesium turnings $(1.55 \mathrm{~g}, 64 \mathrm{mmol})$, a small crystal of iodine and THF $(25 \mathrm{~mL})$. A small amount ( $0.5 \mathrm{~mL}$ ) of a THF solution $(5 \mathrm{~mL})$ of 2,3-dichloropropene (2.22 g, $20 \mathrm{mmol}$ ) was added to the magnesium, the mixture was stirred for about $10 \mathrm{~min}$. and a very exothermic reaction ensued after slightly warming the reaction flask. The allene gas, generated, was bubbled into a solution of $n$-BuLi $(0.65 \mathrm{~mL}, 1.70 \mathrm{mmol})$ in dry diethyl ether $(5 \mathrm{~mL})$ and dry hexanes $(4.35 \mathrm{~mL})$ [32], at $78^{\circ} \mathrm{C}$, contained in the two-necked flask, under nitrogen atmosphere. The remaining THF solution of 2,3dichloropropene was added in small portions, in order to maintain a vigorous generation of allene. It is important to keep a positive pressure of allene during all the process, otherwise a drop in pressure in the three-necked flask, would produce a vacuum in the second flask. To avoid loss of material, during the process of generation of allene, the valve connecting the two-necked flask (containing $n$-BuLi) to a manifold, was kept closed, and the allene was collected into a balloon. After generation of allene stopped, the double-tipped needle was removed from the flask, and the $n$-BuLi-allene solution was stirred at $-78^{\circ} \mathrm{C}$ for 1 hour. After this time a white suspension was obtained, and it was assumed to be about $0.85 \mathrm{mmol}$ of dianion 1,3-dilithiopropyne, 19.

\subsection{Synthesis of 1,3-enyne 11:}

\subsubsection{Synthesis of N-(2,2-diethoxyethyl)-1- Naphthylmethylamine 16:}

To an oven-dried, $50 \mathrm{~mL}$ round-bottom flask, equipped with a magnetic stirring bar, under nitrogen atmosphere, was added 1-naphthylmethylamine $(0.114 \mathrm{~g}, 0.7 \mathrm{mmol})$ and dry THF ( $3 \mathrm{~mL}$ ). The solution was cooled to $0^{\circ} \mathrm{C}$ and a solution of $n$-BuLi in hexanes was added dropwise $(0.30$ $\mathrm{mL}, 0.75 \mathrm{mmol})$. After stirring for 30 minutes, a THF solution $(3 \mathrm{~mL}$ ) of bromoacetaldehyde diethyl acetal, 15 $(0.139 \mathrm{~g}, 0.70 \mathrm{mmol})$ was added and the resulting solution stirred for 18 hours at room temperature. After this time, a saturated $\mathrm{NH}_{4} \mathrm{Cl}$ solution was added $(5 \mathrm{~mL})$ and it was extracted with ether $(2 \times 10 \mathrm{~mL})$. The organic phase was dried over $\mathrm{Na}_{2} \mathrm{SO}_{4}$ and concentrated in vacuo. The residue was purified by column chromatography using a mixture ether:hexane $7: 3$, to give $0.179 \mathrm{~g}$ of product $(94 \%) .{ }^{1} \mathrm{H}$ NMR $\left(400 \mathrm{MHz}, \mathrm{CDCl}_{3}\right) \delta: 1.19(\mathrm{t}, J=7.09 \mathrm{~Hz}, 6 \mathrm{H}), 1.74(\mathrm{~s}$ $1 \mathrm{H}), 2.87(\mathrm{~d}, J=5.54 \mathrm{~Hz}, 2 \mathrm{H}), 3.60(\mathrm{~m}, 4 \mathrm{H}), 4.27(\mathrm{~s}, 2 \mathrm{H})$ $4.65(\mathrm{t}, J=5.53 \mathrm{~Hz}, 1 \mathrm{H}), 7.42(\mathrm{dd}, J=8.07 \mathrm{~Hz}, 1 \mathrm{H}), 7.51(\mathrm{~m}$, $3 \mathrm{H}), 7.77(\mathrm{~d}, J=8.00 \mathrm{~Hz}, 1 \mathrm{H}), 7.86(\mathrm{~d}, J=7.95 \mathrm{~Hz}, 1 \mathrm{H}), 8.13$ $(\mathrm{d}, J=8.57 \mathrm{~Hz}, 1 \mathrm{H}) ;{ }^{13} \mathrm{C} \mathrm{NMR}\left(100 \mathrm{MHz} \mathrm{CDCl}_{3}\right)$ ?]:15.33, $51.63,52.13,62.46,102.28,123.78,123.53,125.74$ 126.17, 126.18, 127.90, 128.83, 131.93, 134.04, 125.91; MS (EI) m/z (rel. intensity) 75 (23), 103 (39), 115 (21), 127 (4), 141 (100), 156 (14), 170 (7), 228 (5), 273 (2); HRMS $\left(E S I, V^{+}\right): m / z[M+H]^{+}$calc. for $\mathrm{C}_{17} \mathrm{H}_{23} \mathrm{NO}_{2} 274.1807$, found 274.1810 .

\subsubsection{Synthesis of $N$-(2,2-diethoxyethyl)-N-methyl-1- Naphthylmethylamine 17:}

To an oven-dried $50 \mathrm{~mL}$ round-bottom flask, equipped with a magnetic stirring bar, under nitrogen atmosphere, was added $\mathrm{N}$-(2,2-diethoxyethyl)-1-naphthylmethylamine (16) $(0.30 \mathrm{~g}, 1.1 \mathrm{mmol})$ and dry THF $(15 \mathrm{~mL})$. The solution was cooled to $0^{\circ} \mathrm{C}$ and a solution of $n$-BuLi in hexanes was added dropwise $(0.55 \mathrm{~mL}, 1.40 \mathrm{mmol})$. After stirring for 30 minutes, a THF $(5 \mathrm{~mL})$ solution of iodomethane, $(0.195$ $\mathrm{g}, 1.40 \mathrm{mmol}$ ) was added and the resulting solution stirred overnight. After this time, a saturated $\mathrm{NH}_{4} \mathrm{Cl}$ solution was added $(5 \mathrm{~mL})$ and it was extracted with ether $(2 \times 10 \mathrm{~mL})$. The organic phase was dried over $\mathrm{Na}_{2} \mathrm{SO}_{4}$ and concentrated in vacuo. The residue was purified by column chromatography using a mixture ether:hexane $4: 6$, to give $0.300 \mathrm{~g}$ of product $(95 \%) .{ }^{1} \mathrm{H}$ NMR $(400 \mathrm{MHz}$, $\left.\mathrm{CDCl}_{3}\right): 1.18(\mathrm{t}, J=7.11 \mathrm{~Hz}, 6 \mathrm{H}), 2.31(\mathrm{~s}, 3 \mathrm{H}), 2.69(\mathrm{~d}, J=$ $5.34 \mathrm{~Hz}, 2 \mathrm{H}), 3.55(\mathrm{~m}, 4 \mathrm{H}), 3.98(\mathrm{~s}, 2 \mathrm{H}), 4.69(\mathrm{t}, J=5.34 \mathrm{~Hz}$ $1 \mathrm{H}), 7.40(\mathrm{~m}, 2 \mathrm{H}), 7.49(\mathrm{~m}, 2 \mathrm{H}), 7.77(\mathrm{~d}, J=7.87 \mathrm{~Hz}, 1 \mathrm{H})$ $7.84(\mathrm{~d}, J=8.10 \mathrm{~Hz}, 1 \mathrm{H}), 8.40(\mathrm{~d}, J=8.40 \mathrm{~Hz}, 1 \mathrm{H}) ;{ }^{13} \mathrm{C} \mathrm{NMR}$ $\left(100 \mathrm{MHz}_{\mathrm{CDCl}}\right)$ : ? 15.43, 43.52, 60.32, 61.63, 61.46, $101.33,125.14,125.17,125.78,125.88,127.64,128.07$ 128.41, 133.98, 135.06, 137.70; MS (EI) m/z (rel. intensity) 75 (8), 103 (8), 115 (21), 141 (100), 171 (10), 184 (51), 242 (6), $287(2)$; HRMS (ESI, $\left.\mathrm{V}^{+}\right): m / z[\mathrm{M}+\mathrm{H}]^{+}$ calc. for $\mathrm{C}_{18} \mathrm{H}_{26} \mathrm{NO}_{2} 288.1964$, found 288.1961.

\subsubsection{Synthesis of N-methyl-N-(1-naphthylmethyl)} acetaldehyde 18:

To an oven-dried, $50 \mathrm{~mL}$ round-bottom flask, equipped with a magnetic stirring bar, and a Libieg condenser, under nitrogen atmosphere, was added $N$-(2,2diethoxyethyl)-N-methyl-1-Naphthylmethylamine 
(0.062 g, $0.2 \mathrm{mmol}), \mathrm{FeCl}_{3} \bullet 6 \mathrm{H}_{2} \mathrm{O}(0,190 \mathrm{~g} ; 0,7 \mathrm{mmol}), 3$ $\mathrm{mL}$ of a mixture of $\mathrm{CH}_{2} \mathrm{Cl}_{2}$ :acetone $(4: 1)$ and $0.3 \mathrm{~mL} \mathrm{HCl}(6$ $\mathrm{mol} / \mathrm{L})$, and the mixture was refluxed for 4 hours. The reaction mixture was allowed to cool to room temperature and a saturated solution of $\mathrm{NaHCO}_{3}(5 \mathrm{~mL})$ was added and extracted with ether $(2 \times 10 \mathrm{~mL})$. The organic phase was washed with water $(3 \times 10 \mathrm{~mL})$ and it was dried over $\mathrm{Na}_{2} \mathrm{SO}_{4}$ and concentrated in vacuo. The crude aldehyde was taken into the next step without any further purification.

4.4.4. (E)-N-Methyl-N-(1-naphthylmethyl)-2-penten-4-ynyl amine 11:

Crude acetaldehyde 18, prepared as above, and assumed to be $\sim 0.2 \mathrm{mmol}$, was dissolved in ether $(3 \mathrm{~mL})$ and added to a 1,3-dilithiopropyne solution, prepared as above (assumed to be $0.85 \mathrm{mmol}$ ) and under nitrogen. The mixture was stirred and allowed to reach room temperature in 3 hours. After this time tosyl chloride $(0.275 \mathrm{~g}, 1.4 \mathrm{mmol})$ dissolved in dry THF $(2 \mathrm{~mL})$ and HMPA (0.80 $\mathrm{mL}, 4.6 \mathrm{mmol})$ was added and stirred at room temperature for 18 hours. The reaction mixture was cooled to $0^{\circ} \mathrm{C}$ and treated with tert-BuLi in pentane (2.0 $\mathrm{mL}, 3.4 \mathrm{mmol}$ ) and stired for three hours. The reaction was quenched by addition of ammonium chloride saturated solution (3-5 mL), extracted with ether $(2 \times 10$ $\mathrm{mL}$ ), dried over $\mathrm{Na}_{2} \mathrm{SO}_{4}$ and concentrated in vacuo. GC analysis of the crude reaction showed a $90 \%$ conversion. The crude reaction was purified by column chromathography (ether:hexane, 1:9) to give $0.010 \mathrm{~g}$ of product. ${ }^{1} \mathrm{H}$ NMR (400 MHz, $\mathrm{CDCl}_{3}$ ): 目 $2.24(\mathrm{~s}, 3 \mathrm{H}), 2.85$ (d, $J=2.41 \mathrm{~Hz}, 1 \mathrm{H}), 3.16(\mathrm{~d}, J=6.20 \mathrm{~Hz}, 2 \mathrm{H}), 3.91(\mathrm{~s}, 2 \mathrm{H}), 5.68$ (dd, $J=2.4,15.8 \mathrm{~Hz}, 1 \mathrm{H}), 6.36(\mathrm{dt}, J=6.3,15.8 \mathrm{~Hz}, 1 \mathrm{H})$, $7.40(\mathrm{~m}, 2 \mathrm{H}), 7.50(\mathrm{~m}, 2 \mathrm{H}), 7.78(\mathrm{~m}, 1 \mathrm{H}), 7.85(\mathrm{~d}, J=8.1$ $\mathrm{Hz}, 1 \mathrm{H}), 8.25(\mathrm{~d}, J=8.1 \mathrm{~Hz}, 1 \mathrm{H}) ;{ }^{13} \mathrm{C} N M R(100 \mathrm{MHz}$, $\mathrm{CDCl}_{3}$ ): $\delta 42.5,59.3,60.3,82.1,87.7,111.2,143.4,124.7$, $125.0,125.2,125.7,126.0,127.5,128.2,128.6,129.7$, 132.5; MS (EI) m/z (rel. intensiy) 65 (9), 94 (14), 108 (7), 127 (5), 141 (100), 155 (22), 220 (18), 234 (20), 235 (5); HRMS $\left(E S I, V^{+}\right): m / z[M+H]^{+}$calc. for $\mathrm{C}_{17} \mathrm{H}_{17} \mathrm{~N} 236.1439$, found 236.1441 .

\subsection{Synthesis of 4-(trans-1-Buten-3-ynyl) $\quad N, N$ Dimethylaniline, 12:}

This enyne was prepared by reaction of 1,3dilithiopropyne, 19, with 4-dimethylaminobenzaldehyde, 22, as described above. ${ }^{1} \mathrm{H} \mathrm{NMR}\left(400 \mathrm{MHz}^{\mathrm{C}} \mathrm{CDCl}_{3}\right)$ : ? 7.28 (d, $J=8.9 \mathrm{~Hz}, 2 \mathrm{H}), 6.97(\mathrm{~d}, J=16.3 \mathrm{~Hz}, 1 \mathrm{H}), 6.65(\mathrm{~d}, J=8.9$ $\mathrm{Hz}, 2 \mathrm{H}), 5.93$ (dd, J=2.3, $16.3 \mathrm{~Hz}, 1 \mathrm{H}), 2,99(\mathrm{~s}, 1 \mathrm{H}), 2.98(\mathrm{~s}$, $6 \mathrm{H}) ;{ }^{13} \mathrm{C}$ NMR $\left(100 \mathrm{MHz} \mathrm{CDCl}_{3}\right)$ : 目 151.02, 143.51, 127.72, 124.29, 112.20, 101.80, 84.21, 77.69, 40.43; MS (EI) m/z (rel. intensity) 77 (12), 115 (8), 127 (37), 128 (8), 141 (3), 155 (15), 171 (100); HRMS $\left(E S I, V^{+}\right): m / z[M+H]^{+}$calc. for $\mathrm{C}_{12} \mathrm{H}_{14} \mathrm{~N}$ 172.1126, found 172.1124 .

\subsection{Synthesis of enyne 13}

\subsection{1. tert-Butyldimethylsilyl 2-Propynyl Ether, $\mathbf{2 5 :}$}

In a $100 \mathrm{ml}$ round botton flask, was added homopropargyl alcohol, 24, (0.56 g, $10 \mathrm{mmol})$, DMF $(10 \mathrm{~mL})$, tertbutyldimethylsilyl chloride ( $1.7 \mathrm{~g}, 13 \mathrm{mmol}$ ) and imidazole $(0.17 \mathrm{~g}, 2.5 \mathrm{mmol})$, and the solution was stirred for $18 \mathrm{~h}$ at room temperature. After this time water $(10 \mathrm{~mL})$ was added to the mixture and extracted with ether $(2 \times 5 \mathrm{~mL})$. The organic extracts were dried over magnesium sulphate and concentrated in vacuo. The residue obtained was purified by Kugelrohr distillation to obtain $1.65 \mathrm{~g}$ of product (97\% yield). ${ }^{1} \mathrm{H} \mathrm{NMR}\left(400 \mathrm{MHz} \mathrm{CDCl}_{3}\right)$ : 目 0.12 (s, $6 \mathrm{H}), 0.91(\mathrm{~s}, 9 \mathrm{H}), 2.38(\mathrm{t}, J=2.54 \mathrm{~Hz}, 1 \mathrm{H}), 4.30(\mathrm{~d}, J=2.54$ $\mathrm{Hz}, 2 \mathrm{H}) ;{ }^{13} \mathrm{C}$ NMR $\left(100 \mathrm{MHz}, \mathrm{CDCl}_{3}\right)$ : ? $-5.06,18.42,25.93$, 51.65, 72.98, 82.57; MS (EI) m/z (rel. intensity) 75 (18), 83 (100), 99 (5), 113 (100), 155 (4), 170 (2); HRMS (ESI, V ${ }^{+}$: $\mathrm{m} / \mathrm{z}[\mathrm{M}+\mathrm{H}]^{+}$calc. for $\mathrm{C}_{9} \mathrm{H}_{19} \mathrm{OSi}$ 171.1205, found 171.1205.

\subsection{2. tert-Butyldimethylsilyl (trans-5-chloro-4-penten-2 ynyl) ether, 26:}

In a three necked, $50 \mathrm{~mL}$, round bottom flask, under nitrogen atmosphere, were added $\mathrm{PdCl}_{2}\left(\mathrm{PPh}_{3}\right)_{2}(0.11 \mathrm{~g}$ 0,15 $\mathrm{mmol})$, trans-1,2-dichloroetene $(2.90 \mathrm{~g}, 30 \mathrm{mmol})$ dry THF $(20 \mathrm{~mL})$ and, the resulting solution, was stirred at room temperature for $20 \mathrm{~min}$. A diethylamine solution (4 $\mathrm{mL}$ ) of acetylene, 25, was added, followed by addition of Cul $(0,06 \mathrm{~g} ; 0,15 \mathrm{mmol})$ and the reaction mixture was stirred at room temperature overnight. The reaction was quenched by addition of saturated ammonium chloride solution $(5 \mathrm{~mL})$, and extracted with ether $(2 \times 10 \mathrm{~mL})$. The organic phase was dried over magnesium sulphate and concentrated in vacuo. The residue obtained was purified by column chromatography (ether:hexane, 1:1) to obtain $1.23 \mathrm{~g}$ of product ( $90 \%$ yield). ${ }^{1} \mathrm{H} \mathrm{NMR}\left(400 \mathrm{MHz} \mathrm{CDCl}_{3}\right)$ : ? $0.12(\mathrm{~s}, 6 \mathrm{H}), 0.91(\mathrm{~s}, 9 \mathrm{H}), 4.41(\mathrm{~d}, J=2.2 \mathrm{~Hz}, 2 \mathrm{H}), 5.95$ (dt, J $=2.2,13.7 \mathrm{~Hz}, 1 \mathrm{H}), 6.51(\mathrm{~d}, J=13.7,1 \mathrm{H}) ;{ }^{13} \mathrm{C} \mathrm{NMR}(100$ $\left.\mathrm{MHz}, \mathrm{CDCl}_{3}\right): \delta-5.00,18.47,25.96,52.23,79.98,90.74$ 113.64, 130.61; MS (EI) m/z (rel. intensity) 73 (12), 99 (8), 143 (100), 145 (33), 173 (58), 175 (18), 215 (2); HRMS $\left(\mathrm{ESI}, \mathrm{V}^{+}\right): \mathrm{m} / \mathrm{z}[\mathrm{M}+\mathrm{H}]^{+}$calc. for $\mathrm{C}_{11} \mathrm{H}_{20} \mathrm{OSiCl} 231.0972$ found 231.0972

\subsubsection{Preparation of $p-N, N,-$ dimethylamino phenyl magnesium bromide, $\mathbf{2 7}$}

To a $50 \mathrm{~mL}$ three necked, round bottom flask, with a Liebig condenser, was added $N, N$-dimethylbromoaniline (0.82 g, $4 \mathrm{mmol})$, magnesium turnings (0.100 g, 4.3 $\mathrm{mmol})$, a small iodine crystal and THF $(4 \mathrm{~mL})$. The mixture was refluxed for $30 \mathrm{~min}$ and a dark solution was obtained.

4.6.4. Preparation of tert-butyl dimethylsilyl-5-trans-( $p$ $N, N$,-dimethylaminophenyl)-4-penten-2-ynyl ether, 28:

In a dry round bottom flask was added $\mathrm{Pd}\left(\mathrm{PPh}_{3}\right)_{4}(0,150 \mathrm{~g}$, $0,13 \mathrm{mmol})$, vinyl chloride 26 (0.573 g, $2.6 \mathrm{mmol})$ and dry THF $(5 \mathrm{~mL})$ and the mixture was stirred for $20 \mathrm{~min}$. After 
this time Grignard, 27, solution, previously prepared, was added dropwise, via canula, and the mixture sitrred for 18 hours at room temperature. After this time, the reaction was quenched by addition of saturated ammonium chloride solution $(5 \mathrm{~mL})$ and extracted with ether $(2 \times 10$ $\mathrm{mL}$ ). The organic extracts were dried over $\mathrm{Na}_{2} \mathrm{SO}_{4}$ and concentrated in vacuo. The residue obtained was purified by column chromathography $\left(\mathrm{Et}_{2} \mathrm{O}\right.$ :hexane, $\left.1: 9\right)$ to give $0.760 \mathrm{~g}$ of 28 (97\% yield). ${ }^{1} \mathrm{H}$ NMR (400 MHz, $\left.\mathrm{CDCl}_{3}\right): 0.15$ (s, 6H), $0.94(\mathrm{~s}, 9 \mathrm{H}), 2.97(\mathrm{~s}, 6 \mathrm{H}), 4.49(\mathrm{~d}, J=2.1 \mathrm{~Hz}, 2 \mathrm{H})$, $5.95(\mathrm{dt}, J=2.1,16.2 \mathrm{~Hz}, 1 \mathrm{H}), 6.65(\mathrm{~d}, J=8.9,2 \mathrm{H})$ ), 6.86 $(\mathrm{d}, J=16.2,1 \mathrm{H}), 7.27(\mathrm{~d}, J=8.9,2 \mathrm{H}) ;{ }^{13} \mathrm{C} N M R(100 \mathrm{MHz}$, $\mathrm{CDCl}_{3}$ ): 目 -4.90, 18.51, 26.05, 40.45, 52.61, 85.15, 88.57, $102.82,112.24,124.69,127.58,141.78,150.83$; MS (EI) $\mathrm{m} / \mathrm{z}$ (rel. intensity) 115 (24), 168 (15), 184 (100), 228 (25), 258 (9), 315 (49), 316 (13); HRMS (ESI, $\left.\mathrm{V}^{+}\right): m / z[M+\mathrm{H}]^{+}$ calc. for $\mathrm{C}_{19} \mathrm{H}_{30}$ NOSi 316.2097, found 316.2091.

\subsection{5. trans-5-(p-N,N-Dimethylaminophenyl)-4-penten-2-} yn-1-ol, 29:

To a THF solution $(10 \mathrm{~mL})$ of silyl ether, $28,(0.370 \mathrm{~g}, 1.17$ mmol) was added, at $0^{\circ} \mathrm{C}$, a $1.0 \mathrm{M}$ THF solution of tetrabutylammonium fluoride $(2.4 \mathrm{~mL}, 2.4 \mathrm{mmol})$ and the resulting solution stirred for $3.5 \mathrm{~h}$. The reaction was quenched by addition of water $(10 \mathrm{~mL})$ and extracted with ether $(2 \times 10 \mathrm{~mL})$. The organic phase was dried $\left(\mathrm{MgSO}_{4}\right)$ and concentrated in vacuo. The residue was purified by column chromatography $\left(\mathrm{Et}_{2} \mathrm{O}\right.$ :hexane, $\left.1: 1\right)$ to give $0,201 \mathrm{~g}$ (85 \% yield). ${ }^{1} \mathrm{H}$ NMR (400 $\left.\mathrm{MHz} \mathrm{CDCl}_{3}\right): 3.00$ $(\mathrm{s}, 6 \mathrm{H}), 4.46(\mathrm{dd}, J=2.2,6.1 \mathrm{~Hz}, 2 \mathrm{H}), 5.97(\mathrm{dt}, J=2.2,16.2$ $\mathrm{Hz}, 1 \mathrm{H}), 6.65(\mathrm{~d}, J=8.8 \mathrm{~Hz}, 2 \mathrm{H}), 6.91(\mathrm{~d}, J=16.2 \mathrm{~Hz}, 1 \mathrm{H})$, $7.27(\mathrm{~d}, J=8.8 \mathrm{~Hz}, 2 \mathrm{H}) ;{ }^{13} \mathrm{C}$ NMR $\left(100 \mathrm{MHz}, \mathrm{CDCl}_{3}\right): \delta$ 40.44, 52.06, 86.17, 87.88, 102.23, 112.23, 124.47, 127.69, 142.44, 150.95; MS (EI) m/z (rel. intensity) 77 (5), 115 (11), 128 (26), 157 (17), 170 (16), 184 (15), 201 (100); HRMS $\left(E S I, V^{+}\right): m / z[M+H]^{+}$calc. for $\mathrm{C}_{13} \mathrm{H}_{16} \mathrm{NO} 202.1232$, found 202.1230 .

4.6.6. trans-5-( $p-N, N$-Dimethylaminophenyl)-4-penten-2yn-1-al, 13:

To a $50 \mathrm{~mL}$ round-bottom flask was added Dess-Martin

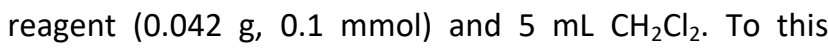
mixture was added alcohol $29(0.010 \mathrm{~g}, 0.05 \mathrm{mmol})$ in $\mathrm{CH}_{2} \mathrm{Cl}_{2}(5 \mathrm{~mL})$ and the resulting mixture stirred for $1 \mathrm{~h}$. The reaction was quenched by addition of a $\mathrm{Na}_{2} \mathrm{~S}_{2} \mathrm{O}_{3}$ solution $(5 \mathrm{~mL})$ and $\mathrm{NaHCO}_{3}$ and it was extracted with ether $(2 \mathrm{x}$ $10 \mathrm{~mL}$ ). The organic extracts were dried over $\mathrm{MgSO} 4$, and concentrated in vacuo. The residue was purified by column chromatography ( $\mathrm{Et}_{2} \mathrm{O}$ :hexane, 9:1) to give 0.009 g of 13 (90\% yield). ${ }^{1} \mathrm{H}$ NMR (400 MHz, $\mathrm{CDCl}_{3}$ ): ? 3.03 (s, $6 \mathrm{H}), 6.03$ (dd, $J=1.2,16.1 \mathrm{~Hz}, 1 \mathrm{H}), 6.65(\mathrm{~d}, J=8.9 \mathrm{~Hz}, 2 \mathrm{H})$, $7.25(\mathrm{~d}, J=16.1 \mathrm{~Hz}, 1 \mathrm{H}), 7.35(\mathrm{~d}, J=8.9 \mathrm{~Hz}, 2 \mathrm{H}), 9.31(\mathrm{~d}, J=$ $1.2 \mathrm{~Hz}, 1 \mathrm{H}) ;{ }^{13} \mathrm{C} N M R\left(100 \mathrm{MHz} \mathrm{CDCl}_{3}\right)$ : 目 40.26, 91.09, $98.58,111.95,123.15,129.10,147.24,150.32,170.65$,
176.58; MS (EI) m/z (rel. intensity) 77 (9), 115 (7), 127 (26), 128 (26), 140 (4), 155 (18), 170 (38), 198 (30), 199 (100); HRMS $\left(E S I, V^{+}\right): m / z[M+H]^{+}$calc. for $\mathrm{C}_{13} \mathrm{H}_{13} \mathrm{NO}$ 200.1075, found 200.1076 .

\section{Acknowledgments}

We thank the University of Costa Rica for financial support, Sistema de Estudios de Posgrado (SEP-UCR) for a stipend to J.A.B.; Lorena Hernández of CIPRONA-UCR for high resolution mass spectra determination and School of Chemistry for NMR determination.

\section{Conflicts of interest}

The authors declare that there is no conflict of interest.

\section{References}

[1]. Täuber A, Müller-Goymann CC. (2014). Comparison of the antifungal efficacy of terbinafine hydrochloride and ciclopirox olamine containing formulations against the dermatophyte Trichophyton rubrum in an infected nail plate model. Mol Pharm., vol. 11, pp. 1991-1996.

[2]. Westerberg DP, Voyack MJU. (2014). Onychomycosis: Current trends in Diagnosis and Treatment. Ind J Clin Pract., vol. 25, pp. 309-319.

[3]. Ellis DH, Watson AB, Marley JE, Williams TG. (1997). Nondermatophytes in onychomycosis of the toenail. $\mathrm{Br}$. J .Dermatol. vol. 136, pp. 490-493.

[4]. Rodrigues Araujo Ce, Carvalho Miranda K, de Aquino Lemos J, Rodrigues Costa C, Kioko Hasimoto L, Sena Passos X, Meneses e Silva H, Rodrigues Silva MR. (2009). Comparison of in vitro activity of five antifungal agents against dermatophytes, using the agar dilution and broth microdilution methods. Rev Soc Bras Med Trop. Vol. 42, pp. 250-254.

[5]. Bernánderz Torres B, Carrillo AJ, Marín E, del Palacio A, Moorke MK, Valverde A, Serrano M, Guarro J. (2001). In vitro activities of 10 antifungal drugs against 508 dermatophyte strains. Antimicrob. Agent. Chemother. Vol. 45, pp. 2524-2528.

[6]. Piraccini BM, Alessandrini A. (2015). Onychomycosis: A Review. J. Fungi. vol. 1, pp. 30-43.

[7]. Berg JC, Hamacher KL, Roberts GD. (20017). Pseudomycetoma caused by Microsporum canis in an immunosuppressed patient: a case report and review of the literature. J. Cutan. Pathol. vol. 34, pp. 431-434.

[8]. Gross-Martínez NT, Ureña-Sánchez M, Chaves-Madrigal O. (2014). Sensibilidad al fluconazol de aislamientos de Trichophyton rubrum. Acta Médica Costarricense. vol. 56, pp. 23-26.

[9]. Barot BS, Parejiya PB, Patel HK, Gohel MC, Shelat PK. (2012). Microemulsion-based gel of terbinafine for the treatment of onychomycosis: Optimization of formulation using D-optimal design. AAPS PharmSciTech. vol.13, pp.184-192.

[10]. Oxford AE, Raistrick H, Simonart P. (1939). Studies in the biochemistry of micro-organisms: Griseofulvin, $\mathrm{C}(17) \mathrm{H}(17) \mathrm{O}(6) \mathrm{Cl}$, a metabolic product of Penicillium griseo-fulvum Dierckx. Biochem. J. vol. 33, pp. 240-248. 
[11]. European Medicines Agency recommends suspension of marketing authorisations for oral ketoconazole". Press Release. European Medicines Agency. 2013-07-26. http://www.ema.europa.eu/ ema/index.jsp?curl=pages/news_and_events/news/2013/0 7/news_detail_001855.jsp.

[12]. Garcla-Rodriguez LA, Duque A, Castellsague J, PerezGutthann S, Stricker BH Ch. (1999). A cohort study on the risk of acute liver injury among users of ketoconazole and other antifungal drugs. Br J Clin Pharmacol. vol 48, pp. 847852.

[13]. Jue SG, Dawson GW, Brogden RN. (1985). Ciclopirox olamine $1 \%$ cream. A preliminary review of its antimicrobial activity and therapeutic use. Drugs. vol 29, pp. 3330-3341.

[14]. Petranyi G, Ryder NS, Stütz A. (1984). Allylamine derivatives: new class of synthetic antifungal agents inhibiting fungal squalene epoxidase. Science. vol 224, pp. 1239.

[15]. Stütz A, Petranyi G. (1984). Synthesis and antifungal activity of (E)-N-(6,6-dimethyl-2-hepten-4-ynyl)-N-methyl-1naphthalenemethanamine (SF 86-327) and related allylamine derivatives with enhanced oral activity J. Med. Chem. vol 27, pp. 1539-1543.

[16]. Iverson SL, Uetrecht JP. (2001). Identification of a reactive metabolite of terbinafine: insights into terbinafine-induced hepatotoxicity. Chem Res. Toxicol. vol 14, pp. 175.

[17]. https://medical-dictionary.thefreedictionary.com/ onychomycosis.

[18]. Gupta AK, Del Rosso JQ, Lynde CW, Brown GH, Shear NH. (1998). Hepatitis associated with terbinafine therapy: three case reports and a review of the literature.Clin. Exp. Dermatol. vol 23, pp. 64.

[19]. Jain S, Sehgal, VN. (2000). Acrodermatitis enteropathica.Int. J. Dermatol. vol 39, pp. 412-422.

[20].Stütz A. (1987). Allylamine Derivatives-a New Class of Active Substances in Antifungal Chemotherapy. Angew. Chem. Int. Ed. Engl. vol 26, pp. 320-328.

[21]. Azerang P, Sardari S. (2012). Antifungal activity of enynediesters and acetylenic compounds obtained by synthesis and in silico prediction pattern. J. Mycol. Med. vol 22, pp. 230-236.
[22]. Cabezas JA, Poveda R, Brenes JA. (2018). Synthesis, vol 50, pp. 3307-3321.

[23]. Nussbaumer P, Leitner I, Stütz A. (1994). Synthesis and structure-activity relationships of the novel homopropargylamine antimycotics. J. Med. Chem. vol 37, pp. 610-615.

[24]. Nussbaumer, P., I. Leitner, K. Mraz, A. Stutz. (1995). Synthesis and structure activity relationships of side chain substituted analogues of the allylamine antimycotic terbinafine lacking the central amino function. J Med Chem. vol 38, pp.1831-1836.

[25]. Lindsay-Scott P, Charlesworth NG, Grozavu A. (2017). A Flexible Strategy for the Regiocontrolled Synthesis of Pyrazolo[1,5-a]pyrazines. J Org Chem. vol 82, pp. 1129511303.

[26]. Umaña C.A., Cabezas J.A. (2017). Palladium-Catalyzed OnePot Conversion of Aldehydes and Ketones into 4Substituted Homopropargyl Alcohols and 5-En-3-yn-1-ols. J. Org. Chem. vol 82, pp. 9505-9514.

[27]. Corey EJ, Venkateswarlu A. (1972). Protection of hydroxyl groups as tert-butyldimethylsilyl derivatives. J Am Chem Soc. vol 94, pp. 6190-6191.

[28]. Carrillo-Muñoz AJ, Cárdenes CD, Carrillo-Orive B, Rodríguez V, del Valle O, Casals JB. (2005). In vitro antifungal activity of voriconazole against dermatophytes and superficial isolates of Scopulariopsis brevicaulis. Rev Iberoam Micol. vol 22, pp.110-113

[29]. Albengres E, Louet H, Tillement JP. (1998). Systemic antifungal agents. Drug interactions of clinical significance. Drug Safety. vol 18, pp. 83-97.

[30]. Azerang P, Sardari S. (2012). Antifungal activity of enynediesters and acetylenic compounds obtained by synthesis and in silico prediction pattern. J. Mycologie Medicale. vol 22, pp. 230-236.

[31]. Watson SC, Eastham JF. (1967). Colored Indicators for Simple Direct titration of Magnesium and Lithiumreagents. Journal of Organometallic Chemistry. vol 9, pp. 165-168.

[32]. In the current procedure, a solvent ratio $(\mathrm{v} / \mathrm{v})$ of ether : hexanes of $1: 1$ was used, as previously reported: Hooz, J.; Cabezas, J.; Musmanni, S.; Calzada, J. (1990) Org. Synth. vol 69, pp. 120. 